\title{
Analysis of the impediments to English vocabulary learning and teaching
}

\author{
Fahime Farjami, Nader Assadi Aidinlou \\ Department of English Language Teaching, Ahar branch, Islamic Azad University, Ahar, Iran
}

Email address:

fahimefarjami@yahoo.com (F. Farjami),naderasadi@yahoo.com (N. A. Aidinlou)

\section{To cite this article:}

Fahime Farjami, Nader Assadi Aidinlou. Analysis of the Impediments to English Vocabulary Learning and Teaching. International Journal of Language and Linguistics. Special Issue: Language Teaching and Learning Key Principles (LTLKP).

Vol. 1, No. 4-1, 2013, pp. 1-5. doi: 10.11648/j.ij1l.s.20130101.11

\begin{abstract}
Learning a foreign or second language at different levels of proficiency involves the acquisition of a great number of words. Language learners look for effective ways to increase opportunities for retaining new words in long-term memory, but forgetting is a common problem. Language learners often complain that they forget new words soon. The importance of vocabulary learning also poses some challenges for teachers. They like to know in what ways instructional programs might foster the acquisition of so many words. Students face some barriers when they try to assign the vocabularies to their long term memories. In this paper, learners' problems in vocabulary learning are elaborated on and some guidelines are offered to ameliorate or even to remove them. In so doing, it introduces language learning strategies that make vocabulary learning interesting and easy for learners. It also familiarizes teachers with useful techniques and activities for presentation. Ideas and viewpoints put forward by distinguished scholars in this area will be utilized to substantiate the arguments. The purpose of this study is to present practical vocabulary learning strategies that can help learners and to offer influential teaching techniques and activities, which are of help to the teachers.
\end{abstract}

Keywords: Vocabulary Learning, Forgetting, Memory, Mnemonic Devices, Input, Intake

\section{Introduction}

Vocabulary is generally considered as the basic communication tool, and often labeled as the most problematic area by language teachers (Celik \& Toptas, 2010). Even though learners master all grammatical areas in the language, the communication stops when they do not know the necessary word. Strategies used for vocabulary learning have been examined by many researchers, scholars, linguists and language teachers for over the past decades (Levenston, 1979).

According to Oxford (1990), language learners have a serious problem remembering the large amounts of vocabulary necessary to achieve fluency.

Lack of sufficient input and output are the sources resulting in forgetting mentioned by Celce-Marcia (2001), Krashen (1997) and Brown (2000).

Exploring students' ability levels and guessing strategies, Schouten-van Parreren (1989) finds the difficulty of weak pupils with restricted word knowledge to integrate knowledge from different sources, and generalize from words already learned to new words.

It is suggested that teaching vocabulary should not only consist of teaching specific words but also intend at equipping learners with strategies necessary to expand their vocabulary knowledge (Hulstjin, 1993, cited in Morin \& Goebel, 2001).

Oxford (1990) states that the mind can store some 100 trillion bits of information, but only part of that potential can be used unless memory strategies come to the aid of the learner.

Through the process of vocabulary learning words play the role of inputs, and are assigned to the memory (intake). Forgetting occurs when learners cannot remember the words once they have learnt. There are some mnemonic devices (memory strategies) which are of great help to make the words remain in long term memory of the learner in order to deepen the intake of the inputs, and also to ease the retrieval in other stages.

Regarding the learners' problems to learn vocabulary in long term, and the teachers' challenges to teach vocabulary efficiently, practical vocabulary learning strategies and influential teaching techniques of scholars are put forward 
in the present study.

\section{Techniques and Strategies on Vocabulary Learning}

According to McCarthy and Wigglesworth (2001), extensive reading will probably be the main chance for many learners to encounter a wide range of new words. Davies and Pears (2003), Oxford and Crookall (1990), Krashen (1989) and Crow (1986) suggest that intentional learning tasks and rote memorization should be discouraged and new vocabulary items should be presented in contexts rich enough to provide clues to meaning and that students be given multiple exposure to items they should learn. Accordingly, both the explicit and the implicit should be incorporated into the teaching and learning of vocabulary (Eysenck, 1982 ; Brown, Waring and Donkaewbua, 2008; Laufer, 2005; Read, 2004; Nation, 2001).

According to Lewis and Hill (1990), using pictures, real objects and synonyms, miming, defining, examplifying and translation are the eight common techniques of teaching vocabulary.

Based on Lewis (1999), attitudes, time, depth of processing are factors affecting the memory in the process of retrieving and recalling.

Oxford's (1990) taxonomy of language learning strategies contains social, memory, cognitive, meta cognitive, affective, and compensation groups. Gu and Johnson (1996) had two main categories of learning strategies including meta cognitive and cognitive, both of which were subcategorized as guessing, using a dictionary, note-taking, rehearsal, encoding and activating. Also, There are nine clusters of vocabulary learning strategy inventory according to Stoffer (1995) including Strategies involving authentic language use, Strategies used for self motivation, Strategies used to organize words, Strategies used to create mental linkages, Memory strategies, Strategies involving creative activities, Strategies involving physical action, Strategies used to overcome anxiety and Auditory strategies.

Nation (2004) considered the memory strategies to be vital, and Oxford (1990) considered them as "powerful mental tools" in dealing with vocabulary learning difficulties as they make learning easier, faster, more enjoyable, more self-directed, and more transferable to new situations. Johnson and Obi (1993) also found that they may help learning disabled students in the area of spelling and benefit their long-term memory of vocabulary.

Nattinger (1988) believed semantic mapping, and grouping words are very beneficial for classroom activities to increase learners' recall of words. Zaid (1995) mentioned the phases of semantic mapping as "introducing the topic, brainstorming, categorization, personalizing the map, postassessment synthesis".

As (Oxford, 1990; Craik \& Lockhart, 1972; Craik \& Tulving, 1975) put, "depth of processing hypothesis", occurs in vocabulary learning when the learner uses more cognitive energy in manipulating and thinking about a word, and then he is more likely to recall and use it.

According to (Johnson and Pearson, 1984), Spreading Activation Models have a facilitating effect because in the process of associations, links of mental processing is alerted. In this sense, the related sentence is comprehended quicker than an unrelated sentence

\section{Experiments on Vocabulary Teaching and Learning}

Hugh Roderick Rosszell's (2007) in his study at a university in Japan, investigated the effect of vocabulary teaching and learning through extensive reading. He concluded that an approach which coupled extensive reading with intensive vocabulary study represented an option that was both more viable and effective for L2 learners.

Demircio, faculty member of education at Gazi university of Akara, (2010) indicated that young learners get actively involved in the learning of words through drama as a teaching technique which creates supportive intellectual and emotional environment that encourages students to think, and accordingly promotes long-term retention of vocabulary.

What Dana (2006) found in an experiment of teaching vocabulary through the Grammar-Translation Method was that it could not lead to language acquisition and her findings supported the opinions of Thuleen (1996) and tugv Krashen (1987) that the Grammar-Translation Method did not lead to effective vocabulary acquisition and that it should be tempered with other approaches for further promotion of acquisition.

Vocabulary acquisition researchers such as Webb (2009), Schmitt (2008, 2000), Hunt and Beglar (2005), Nation (2001, 1990, 1980), Prince (1996), Siebert (1930) and Thorndike (1908) found that learning word pairs is an effective, as well as time-efficient method to acquire vocabulary knowledge.

Sabo and Light own (1999) concluded that the two measures of "time and learner independence" were very important in vocabulary learning and higher overall English proficiency".

Exploring students' ability levels and guessing strategies, Schouten-van Parreren (1989) found the difficulty of weak pupils with restricted word knowledge to integrate knowledge from different sources, and generalize from words already learned to new words.

Also, Ahmed (1989) concluded that matured learners use strategies more and with deeper processing and greater cognitive effort. Research also indicated that patterns of strategy usage could change over time as a learner either matures or became more proficient in the target language (Nielsen, n.d.).

When An (2006) selected and taught twelve vocabulary 
learning strategies from Schmitt's (1997), he found that key word method, verbal repetition, studying the sound of words were mostly used, while studying a word with a pictorial representation of its meaning, grouping and writing words in their word notebooks were least used, and Students with high perception managed several strategies when applying them.

In their study, Gu and Johnson (1996) concluded that selective attention, self-initiation and deliberate activation of newly learned words consistently predicted both vocabulary size and general proficiency. Other predictors of success were contextual learning, and note-taking strategies, and dictionary.

Rasekh and Ranjbery (2003) found the positive effects of explicit meta- cognitive strategy training on the vocabulary learning through a ten-week treatment.

Nemati (2009) taught the meaning of new vocabulary items through giving synonyms and mini-contexts, and showed the high effect of these strategies on short-term and long-term retention. A study done in Turkey revealed that students beliefs and preferences in using vocabulary learning strategies were related, and semantic mapping technique was more effective than the traditional technique in vocabulary learning.

In a study comparing the gender in terms of vocabulary learning strategy use, Gu (2003a) and Catalán (2003) found that females were more willing to use learning strategies than males.

\section{Implications}

As discussed, dealing with vocabulary learning difficulties is a big concern (Oxford, 1990), and no certain strategy can be applied to vocabulary learning (Fan, 2003).

According to Farjami (2001), through observation and tests, teachers can find the students' problems which are as the result of lack of knowledge or misunderstandings. Accordingly they should provide students with affirmative instructions, and also uncover false assumptions.

Conventional methods of using flash cards, notebook, bilingual and monolingual dictionaries, "shallow" sensory processing contributing to short-term memory in vocabulary learning should be replaced with new learning strategies with "deep" semantic processing leading to long -term memory (Hsiao and Oxford, 2002).As they need greater cognitive (Chen, 2005), teachers should provide examples to teach students on how to process information deeply. Understanding students' beliefs of these strategies helps teachers to design suitable materials and activities, and also managers of the language programs, being aware of individual differences, may spend extra course hours focusing on specifically strategy training, and (Carrel, 1984) on parallel concept/background knowledge development. Memory strategies enable students to study on the vocabularies in such a way that they can not only deal with the unknown words and discover their meaning but also use them meaningfully in a context and have little chance to forget them. With the help of strategy training, the more students learn the vocabularies on their own, the better attitudes they have and the more motivated they are towards the language. Using memory strategies generally engages in associating different types of material. That's why they are helpful in learning new vocabulary items and remembering them in the long term memory. Learners will also be more secured and self confident as these strategies activate their background information, and they are open to new vocabularies.

\section{References}

[1] Ahmed, M. O. (1989). Vocabulary learning strategies. In P. Meara, (Ed.) Beyond words (pp. 3-14). London: British Association for Applied Linguistics, in association with Centre for Information on Language Teaching and Research.

[2] An, S. C. (2006). A Study on English vocabulary learning strategies. Unpublished master's thesis, National Chiayi University, Taiwan.

[3] Brown, H. Douglas. (2000). Principles of language learning and teaching. Fourth edition. Addison Wesley Longman, Inc.

[4] Brown, R., Waring, R., \& Donkaewbua, S. (2008). Incidental vocabulary acquisition from reading,readingwhile-listening, and listening to stories. Reading in Foreign Language, 20, 136-163.

[5] Carrel, P. L. (1984). Schema Theory and ESL Reading: Classroom Implications and Applications. The Modern Language Journal, 68/4, 332-343.

[6] Catalan, J.M.R. (2003). Sex differences in L2 vocabulary learning strategies. International Journal of Applied Linguistics, 13(1), 54-77.

[7] Celce-Marcia, M. (2001). Teaching English as a Second or Foreign Language. Boston, Massachosetts: Heinel \& Heinel Publishers, a Division of Wadsworth, Inc.

[8] Chen, Y. (2005). Barriers to acquiring listening strategies for EFL learners and their pedagogical implication. TESLEJ 8 (4).

[9] Celik, S. \& Toptas, V. (2010). Vocabulary learning strategies of Turkish EFL learners. Procedia - Social and Behavioral Sciences, 3, 62-71.

[10] Çelik, S., \& Toptaş, V. (2010, May). Vocabulary learning strategy use of Turkish EFL learners. Paper presented at third international ELT conference: telling ELT tales out of school, Department of English Language Teaching, Faculty of Education, Eastern Mediterranean University, Famagusta, North Cyprus.

[11] Craik, F., \& Lockhart, R. (1972). Levels of processing: A framework for memory research. Journal of Verbal learning and Verbal Behavior, 11, 671-684.

[12] Craik. F., \&Tulving. E. (1975). Depth of processing and retention of words in episodic memory. J. Exp. Psychol. Gen. 104: 268-294. 
[13] Crow, J. (1986). Receptive vocabulary acquisition for reading comprehension. Modern Language Journal, 70, 242250 .

[14] Dana, S. (2006). Methods and approaches in vocabulary teaching and their influence on students' acquisition. Master's Thesis. MASARYK UNIVERSITY. Accessed on $15 \quad$ October 2011: http://is.muni.cz/th/104917/pedf_b_a2/bakalarska_prace.pdf

[15] Davies, P., \& Pears, E. (2003) Success in English teaching. Oxford: Oxford University Press.

[16] Eysenck, M.W. (1982). Incidental learning and orienting tasks. In C.R. Puff (Ed.), Handbook of research methods in human memory and cognition. New York: Academic Press.

[17] Fan, M. Y. (2003). Frequency of use, perceived usefulness, and actual usefulness of second language vocabulary strategies: A study of Hong Kong learners. The Modern Language Journal, 87, 222-241.

[18] Farjami, H. (2001). Misconception Analysis: A necessary complement to foreign language teaching. FORUM, Vol 39 no2, April-June 2001 page 14

[19] Gu, Y. (2003a). Vocabulary learning in a second language: Person, task, context, and strategies. TESL-EJ, 7/2, 1-25.

[20] Gu, Y. \& Johnson, R. K. (1996). Vocabulary learning strategies and language learning outcomes. Language Learning, 46/4, 643-679.

[21] Hsiao, T.Y., \& Oxford, R.L. (2002). Comparing theories of language learning strategies: A confirmatory factor analysis. The modern Language Journal, 86 (3),368-383.

[22] Hugh Roderick, Rosszell (2007). Extensive reading and extensive vocabulary study in Japanese university. Ed.D, Temple University

[23] Hunt, A. \& Beglar, D. (2005). A framework for developing EFL reading vocabulary Reading in a Foreign Language, 17(1).

[24] Johnson, D., \& Obi, S.C. (1993). Mnemonics: Can you spell it? (ERIC Document Reproduction Service No. ED 394-220)

[25] Johnson, D. D. and Pearson, P. D. (1984). Teaching Reading Vocabulary (2nd Ed.). New York: Holt, Rinehart Winston.

[26] Levenstone, E. A. (1979). Second language vocabulary acquisition: issues and problems. Inter-language Studies Bulletin, 4(2), 147-160.

[27] Kojic-Sabo, I. \& Lightbown, P. (1999). Students approaches to vocabulary learning and their relationship to success. The Modern Language Journal, 83:2,176-192.

[28] Krashen, S. (1989). We acquire vocabulary and spelling by reading: Additional evidence for the Input Hypothesis. Modern Language

[29] Journal, 73, 440-462.

[30] Krashen, S. (1987). Principles and practices in second language acquisition. NewYork: Prentice- Hall.

[31] Laufer, B. (2005). Focus on form in second language vocabulary learning. In S.H. Foster-Cohen, M. Garcia-Mayo, \& J. Cenoz (Eds.), Eurosla Yearbook Volume 5.Amsterdam: Benjamins.
[32] Levenston, E. (1979). Second language vocabulary acquisition: Issues and problems. Interlanguage Studies Bulletin, 4, 147-160.

[33] Lewis, L., \& Hill, J. (1990) Practical techniques for language teaching. London: Language Teaching Publications.

[34] Lewis, Marilyns. (1999). How to study foreign languages. London: Macmillan Press LTD.

[35] McCarthy, M. \& Wigglesworth, G. (2001). Vocabulary teaching and learning special issue. Prospect Journal, 16(3).

[36] Morin, R. \& Goebel, J. (2001). Basic vocabulary instruction teaching strategies or word? Foreign Language Annals, 34 (1), -16 .

[37] Nation, I.S.P. (2004). Teaching and learning vocabulary [M]. Beijing: Foreign language Teaching and Research Press. 159

[38] Nation, I.S.P. (2001). Learning vocabulary in another language. Cambridge: Cambridge University Press.

[39] Nation, I.S.P. (1990). Teaching and learning vocabulary. New York: Newbury House.

[40] Nation, I.S.P. (1980). Strategies for receptive vocabulary learning. Guidelines, 3, 123.

[41] Nattinger, J. (1988). Some current trends in vocabulary teaching. In R. Carter \& M. Mc Carthy (Eds.), Vocabulary and language teaching. London: Longman.

[42] Nemati, A. (2009). Memory vocabulary learning strategies and long-term retention. Retrieved from the Web October 10, 2009, from www.academicjournal.org/ijvte

[43] Nielsen, B. (n.d.) A Review of research into vocabulary learning and acquisition. Retrieved from http://www.kushiroct. ac.jp/library/kiyo/kiyo36/Brian.pdf on January 2010.

[44] Oxford, R. (1990). Language learning strategies: What every teacher should know. New York: Newbury House.

[45] Oxford, R. \& Crookall, D. (1990). Vocabulary learning: A critical analysis of techniques. TESL Canada Journal, 7, 930 .

[46] Prince, P. (1996). Second language vocabulary learning: The role of context versus translations as a function of proficiency. The Modern Language Journal, 80,478-493.

[47] Rasekh, Z. E. \& Ranjbary, R. (2003). Meta cognitive strategy training for vocabulary learning. TESL-EJ, 7/2, 115.

[48] Read, J. (2004). Research in teaching vocabulary. Annual Review of Applied Linguistics, 24, 146-161.

[49] Schmitt, N. (2008). Instructed second language vocabulary learning. Language Teaching Research, 12, 329-363.

[50] Schmitt, N. (2000). Vocabulary in language teaching. Cambridge: Cambridge University Press.

[51] Schmitt, N. (1997). Vocabulary learning strategies. In N. Schmitt X M. Mc Carthy (Eds.), vocabulary: description, acquisition and pedagogy (pp. 199-228).Cambridge: Cambridge University Press. 
[52] Schouten-van Parreren, C. (1989). Vocabulary learning through reading: which conditions should be met when presenting words in texts? AILA Review, 6,7585.

[53] Siebert, L. (1930). An experiment on the relative efficiency of studying French vocabulary in associated pairs versus studying French vocabulary in context. Journal of Educational Psychology, 21, 297-314.

[54] Stoffer, I. (1995). University foreign language students choice of vocabulary learning strategies as related to individual difference variables. Unpublished $\mathrm{PhD}$ Dissertation; University of Alabama, Alabama.

[55] Thorndike, E. (1908). Memory for paired associates. Psychological Review, 15, 122138.
[56] Thuleen, N. (1996). The Grammar-Translation Method. Accessed on 15 October 2011: http://www.nthuleen.com/papers/720report.html

[57] Webb, S. (2009). Effects of receptive and productive learning of word pairs on vocabulary knowledge.Accessedon11October 2011: http://www.sagepub.co.uk/journalsPermissions.nav

[58] Zaid, M. A. (1995). Semantic Mapping in Communicative Language Teaching English Teaching Forum, 33, 6-7. -54). New York: Oxford University PressInc 